\section{フェライト系ステンレス鋼の自動車 排気系部品への適用一(2)}

Q 自動車用排気ガス系部品としてフェライト系ステ ンレス鋼を用いたい。鋼種の選定に対し試験・評価法を お教え下さい。特にガス組成との関連をどう評価すべき か, 発生する腐食形態や寿命評価法の例などを和教え下 さい。

\section{A 1. 自動車排気ガス部品の腐食環境}

自動車に対する最近の社会的ニーズは, CAFE 法案に 見られるような地球環境の污染防止が最大のものであ る。このため, 自動車には限りなき高性能化と排気ガス 対策が求められており, 使用材料も高強度化と高寿命化 を念頭に括いた開発と材料変更が行われている。

自動車排気系部品の分野でも, 従来使用されていた鋳 鋼や亜鉛めっき鋼板から Al めっき鋼板やステンレス鋼 へと変化してきた1)。今後, 排気ガス浄化に対する負荷 の増加に伴って排気系の腐食環境が激化することから, ますますステンレス鋼化, 中でも熱膨張率が小さく熱伝 導度の大きいフェライト系ステンレス鋼の適用への動き が加速されるものと思われる。

自動車排気系の代表的な例を図 1 に模式的に示した2）。 エンジンからの排気ガスは, エキゾーストマニホールド から触媒コンバータ, マフラを経て大気中に放出される。 排気ガスの組成や温度はこの過程で変化し, マフラ以降 の低温域では腐食性ガス成分の凝縮が起こる。腐食環境 としては, これらの要因に季節や走行状態, 走行地域, 燃料の種類などの影響が加わる上に, 乾湿や加熱冷却が 不定周期で繰り返されるため, 極めて複雑である。

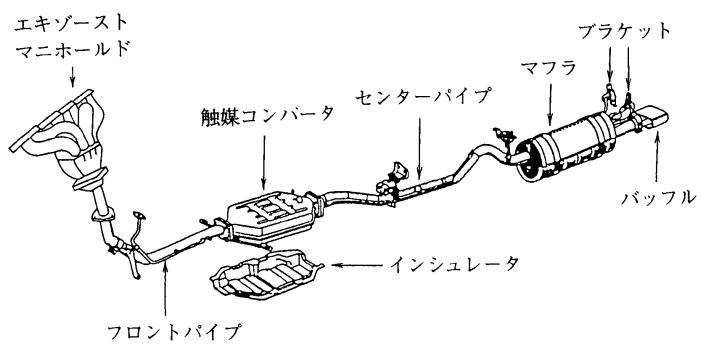

図 1 自動車排気系模式困

\section{2. 自動車排気ガス部品の腐食型態とその発生機構}

エキゾーストマニホールドから触媒コンバータまでの 高温域に生ずるステンレス鋼の腐食は, 排気ガスの温度
が $800^{\circ} \mathrm{C}$ 以上であるため, 高温酸化が主体である。しか し, 排気ガスには $\mathrm{CO}, \mathrm{CO}_{2}, \mathrm{O}_{2}, \mathrm{H}_{2} \mathrm{O}$ の他に $\mathrm{N}_{2}$, 炭化 水素, $\mathrm{SO}_{x}, \mathrm{NO}_{x}$ などが含末れて括り, 大気中に比べて 酸化速度は大きく短時間でノジュール状（生成酸化物で こぶ状にふくらんだ）の Fe の急速酸化が起こる。

また，エキゾーストマニホールドは熱遮蔽版で覆われ てはいるが, 触媒コンバータに至るパイプ系は大気環境 にさらされているため, 特に寒冷地の場合, パイプ外面 に融雪塩が付着して溶融し局部的な溶融塩酸化が生ずる 場合がある3)。

触媒コンバータ以降特にマフラでは, 低温となるので 高温酸化は軽減するが, 内面に凝縮液による湿式腐食が 発生する。凝縮液には $\mathrm{Cl}^{-}, \mathrm{SO}_{4}{ }^{2-}, \mathrm{NH}_{4}{ }^{+}$などのイオン が含まれ 電気電導度が大きいので，その腐食形態は全 面腐食や孔食状の局部腐食となる。さらに, 構造的な隙 間部分には隍間腐食も生ずる。これらの腐食形態は $\mathrm{Al}$ めっき鋼などの耐食性レベルの低い鋼材では全面腐食 が，耐食性の高いステンレス鋼では局部腐食が主体とな る。

また,これらの部品は大気環境にさらされているため, 外面に泥などの付着物直下を起点とした孔食や赤錆が発 生する。温度の大幅な変動が不可避な部位であり乾湿の 繰り返しも激しいため, 自動車の外板やモールなどより はるかに発銹が起こりやすい。

\section{3. 腐食および酸化の試験・評価方法}

排気ガス中での鋼材の高温酸化特性は，基本的には大 気中の特性に準じて評価することが可能である。しかし， 排気ガス中は清浄な大気中に比べるとはるかに縓しい環 境であるので, 酸化速度は大きくノジュール状酸化の開 始する温度や時間は大気中に比べ低温短時間になる。従 って, 鋼材の評価は, まず大気中での高温酸化特性の傾 向を把握し，次いで実環境での高温酸化特性の判明して いる現行材料を基準にして夷環境中での高温酸化特性や 寿命を相対的に推定するといら方法で行われている。

この方法では, 絶対的な高温酸化特性や寿命を評価す ることができない。このため, エンジンから直接排気ガ スを導入したり実排気ガスをシミュレーションして，よ り実車の環境に近い雾囲気の中で断続加熱繰り返し試験 を行い，材料特性を評価している。

触媒コンバータ以降の特にマフラの凝縮液による湿式 腐食の評価には，これまで種々の方法が提案されてき た ${ }^{5), 8)}$ 。かし，エンジンの改良などによってマフラの 凝縮液の組成も变化するために, 次第に実車試験や実環 境試験との対応が十分でなくなり, 評価シミュレーショ ン試験も変更していかざるを得ない。従って, 鋼材の耐 食性評価は，鋼材メーカーや自動車メーカーがその時に 
応じて腐食試験方法や条件を定め, 実車試験の結果を参 考にしながら考察を加えて推察する方法で実施してい る。

ほとんどの評価試験は，マフラの凝縮液を模した溶液 を用いて電気化学特性を解析したり ${ }^{4)}$, 乾湿や結露水結 などを繰り返すいわゆるサイクリックな腐食環境シミュ

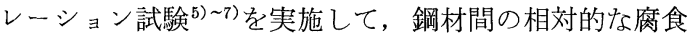
特性や寿命推定を行っている。表 1 に, Chlysler 社で実 施している方法を示した。

表 1 Chlysler 社でのマフラ用材料腐食評価試験 方法

\begin{tabular}{|c|c|c|}
\hline 試験溶液 & \multicolumn{2}{|c|}{$0.01 \mathrm{~N}-\mathrm{HBr}+0.05 \mathrm{~N}-\mathrm{H}_{2} \mathrm{SO}_{4}$} \\
\hline 験試温度 & \multicolumn{2}{|l|}{$180^{\circ} \mathrm{F}\left(82^{\circ} \mathrm{C}\right)$} \\
\hline 試験方法 & 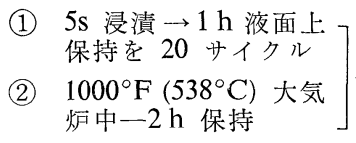 & $\begin{array}{l}80 \text { サイクル } \\
-(240 \mathrm{~h}) \text { 繰り } \\
\text { 返し }\end{array}$ \\
\hline 価 & \multicolumn{2}{|c|}{ 板厚減少 $0.002^{\prime \prime}(0.051 \mathrm{~mm})$ 以下を合格 } \\
\hline
\end{tabular}

\section{4. 対策の考え方}

これまで述べたように，自動車用排気ガス系部品でも エキゾーストマニホールドから触媒コンバータまでの高 温部の部品と触媒コンバータ以降の低温部では材料選択 の基準が異なる。

高温部に使用する部品では, 耐熱性や耐高温酸化性が 優れたフェライト系ステンレス鋼, 中でも $\mathrm{Ti}$ を添加し た AISI $409 \mathrm{~L}$ 鋼 $(11 \mathrm{Cr}-0.2 \mathrm{Ti}$ など) や SUS $430 \mathrm{LX}$ 鋼 (19Cr-0.4Nb-0.4Cu など）が使用されている ${ }^{8)}$ 。特に SUS 430 LX 鋼は, 図 2 に示したように耐高温酸化性が 優れ高温強度も高いことから, 今後増加することが考觉 られる。また, 高温部の部品の中には, フレキシブルパ イプのよらに非常に敛しい加工を行うものがある。この ような部品では高温特性に加えて優れた加工性が要求さ

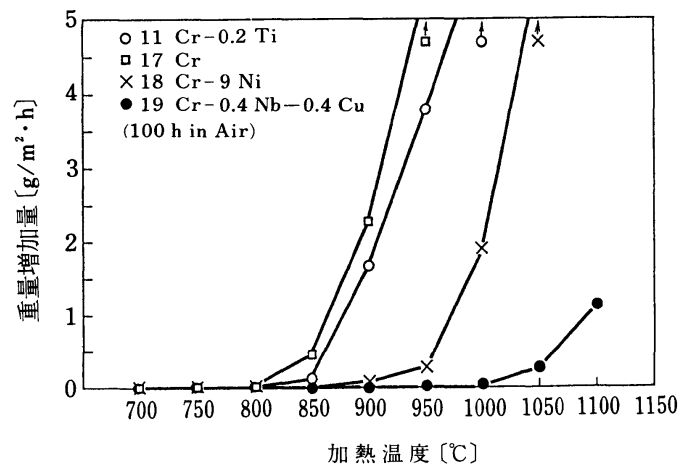

図 2 ステンレス鋼の大気中耐高温酸化特性 $(100 \mathrm{~h})$
れるが，今のところフェライト系ステンレス鋼では対応 できず, SUS 304 鋼をはじめ Si や Nbを添加したオー ステナイト系ステンレス鋼が用いられている。

低温部に使用する部品は, 内面の排気ガス凝縮液に対 する耐食性と外面の耐銹性が要求される。模擬凝縮液中 では，図 $3^{4)}$ に示したように Cr や Mo の影響が大きい ことが認められている。現在, マフラにはAISI 409L 鋼 や $\mathrm{Al}$ めっきステンレス鋼が使用されている ${ }^{8)}$ 。特に, テ ールパイプのように外見できる部品では耐銹性が重要な 特性となり， $\mathrm{Nb}, \mathrm{Cu}$ を添加して優れた耐銹性を有する SUS 430 LX 鋼8),9)への材料シフトが進行している。

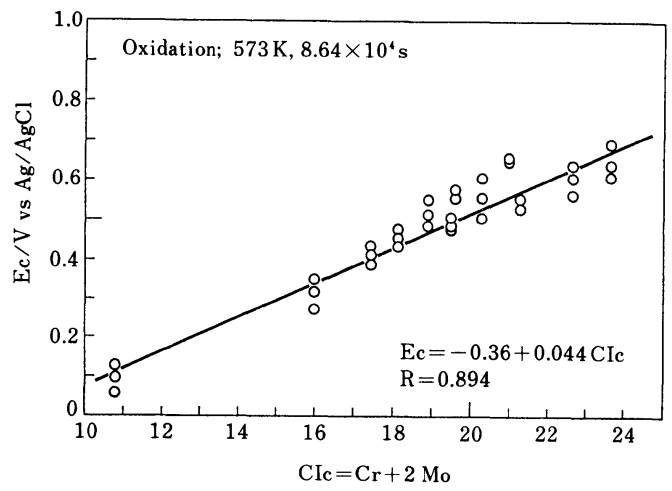

図 3 マフラ凝縮液環境中での孔食電位に及ぼす Cr 和よび Mo の影響4

文献

1) R. Grundmann und W. Borges: Thyssen Tech. Ber., 20 [2], 399 (1988).

2)卜ヨタ自動車サービス部：「自動車の構造」p. 71 (1985).

3）持館 武：ステンレス協会自動車委員会および調 査統計委員会共催「自動車とステンレス」座談会 資料 (1988).

4) 佐藤栄次, 松橋 亮, 伊藤 䟾, 安保秀雄: 腐食 防食 '90 予稿集, 263 (1990).

5）渡辺 孝：自動車技術，30 [11] 886 (1976).

6) 足立俊郎, 吉井紹泰, 藤田昇平, 篠田研一：鉄々 鋼, 71 [5] S 670 (1985).

7) 富士川尚男, 高祖正志, 宮原光雄, 時政勝行, 樋 口賢次：住友金属, 41 [2] 215 (1989).

8） ステンレス協会自動車委員会：ステンレス，33 [12] 12 (1989).

9）山本章夫, 芦浦武夫：防食技術, 37, 407 (1988). (山本章夫*)

* 新日本製鐵 (株) 室闌技術研究部 (下050 室蘭市仲 町 12) 